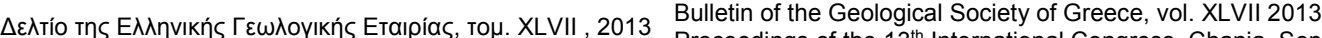

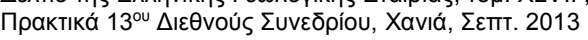

\title{
DEVELOPMENT OF INNOVATIVE ENVIRONMENTAL APPLICATIONS OF ATTAPULGITE CLAY
}

\author{
Zotiadis V. ${ }^{1}$ and Argyraki A. ${ }^{2}$ \\ ${ }^{1}$ EdafomichanikiS.A.,vzotiad@edafomichaniki.gr \\ ${ }^{2}$ National and Kapodistrian University of Athens, Faculty of Geology and Geoenvironment, \\ Department of Economic Geology and Geochemistry, argyraki@geol.uoa.gr
}

\begin{abstract}
In this paper we present a series of laboratory and field, pilot- scale applications of attapulgite clay as an amendment for the stabilization of metals in contaminated soil and sewage sludge. Attapulgite's structure together with its fine particle size and fibrous habit are responsible for its high specific surface area and sorption properties. A pilot scale application of attapulgite clay as a binder for in situ stabilization of toxic metals in contaminated land showed significant reduction in the water leachable metal fraction (Cu: 17\%, Pb: 50\%, $\mathrm{Zn}: 45 \%$, Cd: 41\%, $\mathrm{Ag}: 46 \%$, As: 18\%, Mn: 47\%, Ba: 45\%, Sb: 29\%). In a second pilot scale environmental application, an innovative attapulgite "Geosynthetic Reactive Clay - GRC" was designed and developed for "capping" and "stabilization" of toxic metals in contaminated soil. Also, laboratory scale experiments with fresh sewage sludge from a municipal water treatment plant showed that addition of attapulgite clay in sludge, significantly reduced the leachable concentrations of phenol, $\mathrm{DOC}, \mathrm{Hg}, \mathrm{Cu}, \mathrm{Mo}, \mathrm{Pb}, \mathrm{Se}, \mathrm{As}, \mathrm{Zn}$ and pathogen population over a 4 weeks observation period. The developed soil remediation techniques are promising and cost-effective under present market conditions. Concerning treatment of sewage sludge, attapulgite clay is an effective additive that could enhance the composting procedure creating an environmental added value, final compost product.
\end{abstract}

Key words: Palygorskite, soil remediation, sewage sludge treatment, heavy metals.

\section{Пєрí $\eta \psi \eta$}

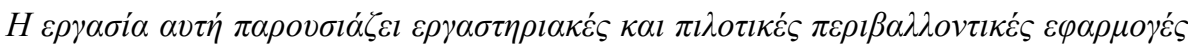

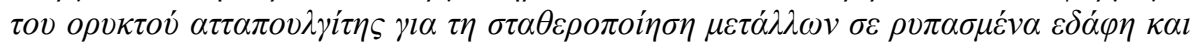

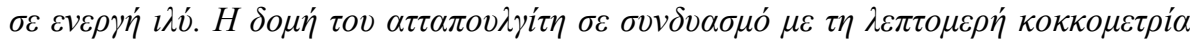

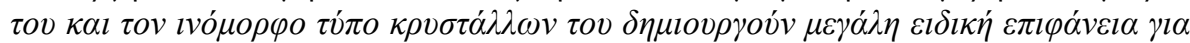

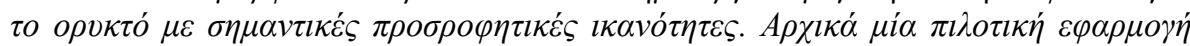

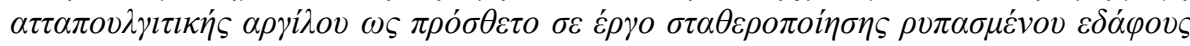

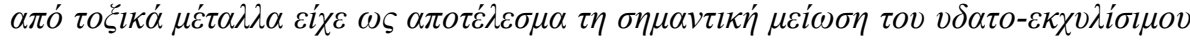
$\kappa \lambda \dot{\alpha} \sigma \mu \alpha \tau o \varsigma \tau \omega v \mu \varepsilon \tau \dot{\alpha} \lambda \lambda \omega v$ (Cu: 17\%, Pb: 50\%, Zn: 45\%, Cd: 41\%, Ag: 46\%, As:

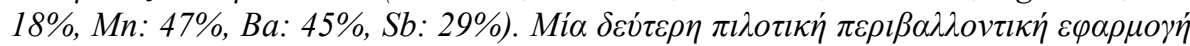

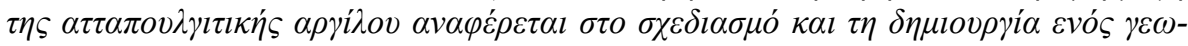

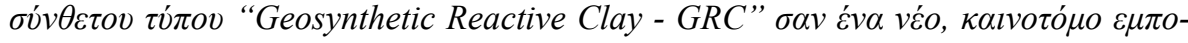

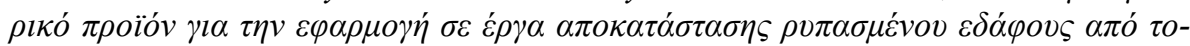

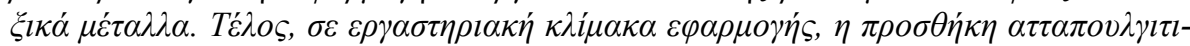

XLVII. No $2-992$ 


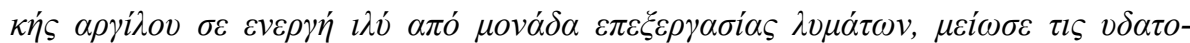

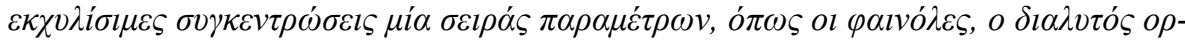

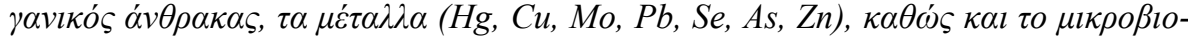

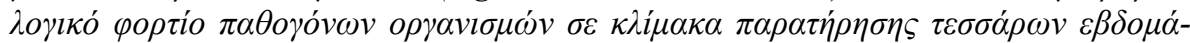

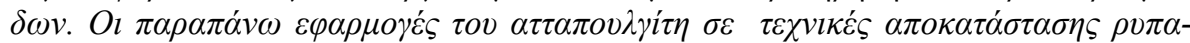

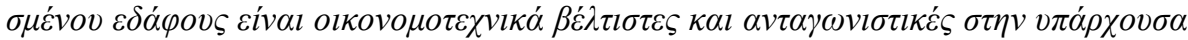

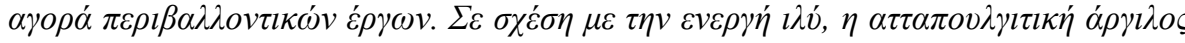

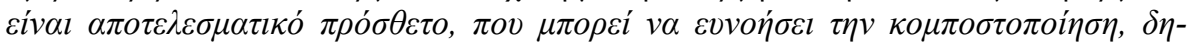

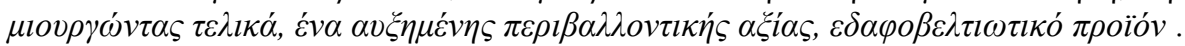

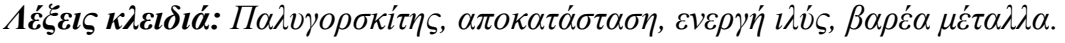

\section{Introduction}

The use of mineral-based amendments for remediation of metal and organic contaminants in soils has been widely studied and is gaining broader acceptance as a cost effective remediation technology (O'Day and Vlassopoulos, 2010). The overall aim of in situ amendment technologies is to sequester and stabilize contaminants in soils or biosolids in order to reduce their ability to partition to water or biota, thus decreasing their potential for transport and toxicity. The selection of appropriate amendments is an open field for research on the quest for the most effective mixing proportions at an affordable cost. Environmental applications of attapulgite clay as an effective toxic metal absorbent have previously been described in laboratory scale by many researchers (Álvarez-Ayuso et al., 2003; Shirvani et al., 2006; Potgieter et al., 2006; Veli et al., 2007; Zhang and $\mathrm{Pu}, 2010)$ for contaminated land remediation. However, there are not any studies on larger scale experiments involving applications in the field. In this paper we present a series of pilot scale and batch scale applications of attapulgite clay as an amendment for the stabilization of metals in contaminated soil and sewage sludge.

\section{Materials and Methods}

\subsection{Attapulgite Clay}

Attapulgite's (palygorskite) structure consists of modulated 2:1 layers, demonstrating a variable dioctahedral to trioctahedral character expressed by the following general chemical formula $\mathrm{Mg} 5 \mathrm{Si} 8 \mathrm{O} 20(\mathrm{OH}) 2(\mathrm{OH} 2) 4.4 \mathrm{H} 2 \mathrm{O}$ (Gionis et al., 2006). The presence of micropores and channels in attapulgite's structure together with its fine particle size and fibrous habit are responsible for its high specific surface area and its sorption properties (Galan, 1996). The attapulgite clay used in the lab and pilot scale applications presented in this paper are commercial products of Geohellas S.A. selected to fit the design of the specific environmental applications. The raw material is originated from deposits exploited by Geohellas at Grevena, Greece. A typical mineralogical composition of attapulgite clay consists mainly of palygorskite, saponite and quartz with minor amounts of calcite, serpentine, dolomite and occasionally plagioclase and pyroxene. A representative XRD pattern of palygorskite rich attapulgite clay especially selected for the presented applications is given in Figure 1.

\subsection{Experimental Design Principles and Concept Application}

The tested environmental applications of attapulgite clay as amendment for environmental applications refer to three completed projects that are discussed in the following paragraphs.

\subsubsection{Pilot Scale Application of Attapulgite Clay for In Situ Stabilization Toxic Metals in Contaminated Land}

The contaminated site for this experiment was located in a public recreational area in Lavrion town, $55 \mathrm{~km}$ southeast of Athens, Greece. Field dimensions were $9 \mathrm{~m} \mathrm{x} 12 \mathrm{~m}$ and the overburden 
material consisted of a mixture of alluvial soil and mining/ metallurgical waste at least to a depth of $30 \mathrm{~cm}$. Detailed description of site history as well as contaminated soil conditions are given in Zotiadis et al. (2012). Preparation of the study area included rotor-tilling to a depth of $30 \mathrm{~cm}$, manual removal of large cobbles and rewetting the soil to amend the initial soil moisture content. Physical properties of contaminated soil were determined by geotechnical laboratory tests. Soil treatment included addition of appropriate amount of attapulgite clay, mixing, homogenization and rewetting to attain saturated conditions. Homogenization of treated soil was repeated on a weeklybasis for a one month period (4 weeks), using a rotor-tiller in parallel with soil rewetting to maintain near-saturation soil conditions. Soil $\mathrm{pH}$ was monitored weekly. A final set of samples was collected at the end of the 4 weeks period to study the final geochemical characteristics of the study area while $\mathrm{pH}$ monitoring continued for a period of seven (7) months on a monthly basis.

\subsubsection{Pilot Scale Application of a "Geosynthetic Reactive Clay - GRC" as an Innovative Product for the Retention of Toxic Elements in Contaminated Land}

This case study included the design and application of a "capping" technique for remediation of heavily contaminated soil by toxic metals and is a reference project for the commercial production of GRC product. A new Geosynthetic Clay Composite was developed by substituting impermeable Na-bentonitic clay with permeable attapulgite clay, thus creating an innovative product for the retention of toxic elements in contaminated land (Kollios and Zotiadis, 2012).

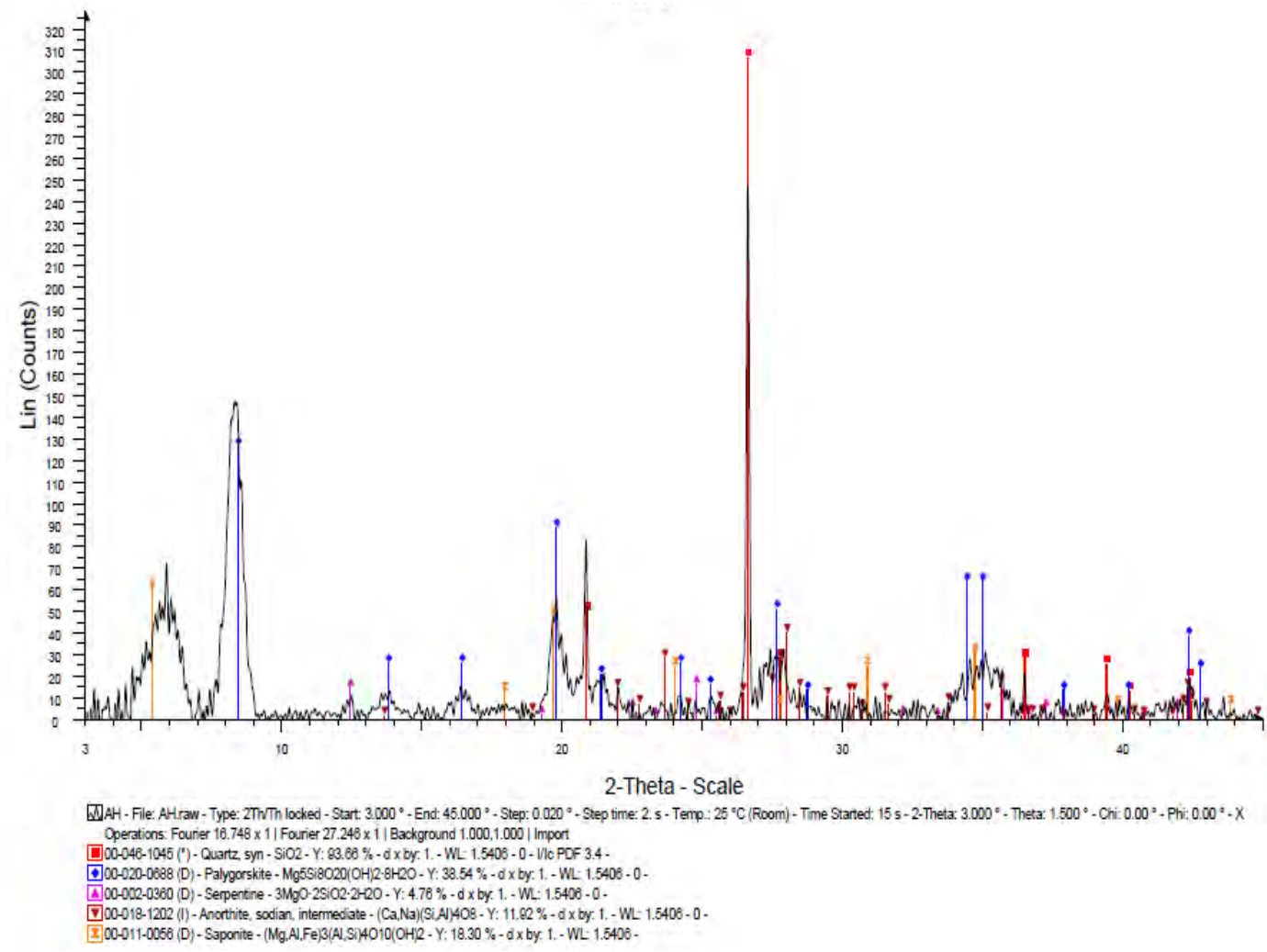

Figure 1 - XRD pattern of a typical palygorskite rich attapulgite clay.

The product was tested in a Primary School yard at Lavrion, Greece. High recorded concentrations of toxic elements in soil and dust of the area are reflected in adverse effects in human health. The aim was to limit the exposure of children to soil containing toxic metals by developing a relatively low cost product with simple construction requirements. The school building was founded in a 4.5 $\mathrm{m}$ thick hazardous waste layer consisting of alluvial soil mixed with historical mining and 
metallurgical waste (carbonate-rich tailings and slag). Below this depth, Quaternary deposits of alternations of conglomerates and marls continue for 3 to $10 \mathrm{~m}$ until they meet the alpine geological basement of metamorphic schist. The contaminated subsoil/soil layer was characterized by determining geotechnical, mineralogical and geochemical parameters prior to the application of attapulgitic GRC. According to the defined geotechnical and geochemical properties, the remediation actions included: a) ex-situ excavation of the contaminated soil/subsoil to the depth of $40 \mathrm{~cm}, \mathrm{~b})$ placement of a non-woven geotextile over the contaminated subsoil, c) placement of a layer of granular attapulgite clay with thickness of $10 \mathrm{~cm}, \mathrm{~d}$ ) covering the attapulgite clay with a second non-woven geo-textile and, e) placement of a layer of clean vegetal soil with a thickness of $30 \mathrm{~cm}$ for planting purposes, according to the landscape design.

Leaching experiments were conducted on representative, three fold composite samples of contaminated soil, clean soil and attapulgite clay according to EN 12457-4 (2003) European Standard (one stage batch test at a liquid to solid ratio of $10 \mathrm{~L} / \mathrm{Kg}$ ). Additionally, up flow percolation tests were performed on two (2) subsamples according to the technical specification CEN/TS 14405 (2004). The testing column was designed and packed with the used materials (contaminated soil, geotextile, attapulgite clay, geotextile, vegetal soil) according to the proposed design in order to examine the effectiveness of different thickness of the attapulgite clay layer (i.e. $0 \mathrm{~cm}, 5 \mathrm{~cm}, 10 \mathrm{~cm}, 15 \mathrm{~cm})$.

\subsubsection{Laboratory Scale Application of Attapulgite Clay for Treatment of Sewage Sludge from the Municipal Wastewater Treatment Plant of Kamari, Thera}

The objectives of this laboratory scale study were to assess the effectiveness of two modified attapulgite clay samples with different grain size distribution, mixed in two different proportions with sludge material (Gidaropoulou et al., 2012). Two types of heat treated material were tested, differing in their grain size distribution; a fine grained sample (F) with particle size distribution $(\mu \mathrm{m})$ of $\mathrm{d} 10=1.8, \mathrm{~d} 50=8.9, \mathrm{~d} 90=24.8$ and a coarse grained sample $(\mathrm{C})$ with $90 \%$ of grains in the 20/50 mesh size.

Sampling of sewage sludge material was conducted in September 2011 at the Kamari treatment plant. Twenty four hours after collection the sludge was weighted and placed into 5 orthogonal polypropylene flower pots of dimensions $25 \times 25 \times 50 \mathrm{~cm}$, each containing $12 \mathrm{~kg}$ of material. Attapulgite clay was added into four of the sludge containing pots; the material in the fifth pot was left untreated in order to provide a reference sample (SLU). Mixing proportions of each of the fine and coarse grained attapulgite clay samples were $5 \%$ and $10 \%$ on a dry weight basis. The amended material was homogenized manually and the pots were kept in open air conditions protected from rain and direct sunlight for a period of 4 weeks. Mixing and homogenization of sludge was repeated on a weekly basis during this period and the $\mathrm{pH}$ of the material was monitored weekly. A final set of samples was removed from the pots at the end of the 4 weeks period to study the final geochemical and microbiological characteristics of sludge.

Aliquots of untreated and treated sludge samples were subjected to the $\mathrm{L} / \mathrm{S}=10$ leaching procedure with deionized water according to EN 12457-4 (2003). Chemical analysis of heavy metals was performed in parallel in the Laboratory of Economic Geology and Geochemistry, University of Athens by using graphite furnace atomic absorption spectroscopy and an accredited external laboratory. Appropriate analytical techniques were used for the determination of the total parameters prescribed by the Council Decision 2003/33/EC. Microbiological analysis was also performed on sludge before and after treatment to determine the following parameters: Coliforms, Fecal coliforms, $\beta$-glucuronidase positive E. coli, Enterococci, Salmonella spp, Listeria monocytogenes. This analysis was performed in the external accredited laboratory. Furthermore the sludge samples were studied by X ray diffraction using a Siemens D-5005 diffractometer with $\mathrm{Cu} K \alpha$ radiation and scanning electron microscopy (SEM) using a JEOL JSM-5600 system at the Laboratory of Economic Geology and Geochemistry, University of Athens. 


\section{Results and Discussion}

\subsection{In Situ Stabilization Toxic Metals in Contaminated Land}

The descriptive statistics of water leachable concentrations in untreated and treated soil samples from the pilot scale study in Lavrion are presented in Table 1. Before treatment the determined water leachable metal concentrations exceeded the limit values for inert waste assigned by Directive 2003/33/EC.

Table 1 - Water leachable elemental concentrations $(\mu \mathrm{g} / \mathrm{kg})$ before and after in-situ treatment of Lavrion urban soil with attapulgite clay $(n=12)$.

\begin{tabular}{|c|r|r|r|r|r|r|r|r|}
\hline \multirow{2}{*}{ Element } & \multicolumn{2}{|c|}{ Mean } & \multicolumn{2}{c|}{ Min } & \multicolumn{2}{c|}{ Max } & \multicolumn{2}{c|}{$\begin{array}{c}\text { Standard } \\
\text { Deviation }\end{array}$} \\
\cline { 2 - 9 } & untreated & treated & untreated & treated & untreated & treated & untreated & treated \\
\hline $\mathrm{Cu}$ & 544 & 456 & 505 & 329 & 577 & 537 & 34 & 83 \\
\hline $\mathrm{Pb}$ & 9198 & 4609 & 6491 & 3146 & 11109 & 6267 & 2325 & 1179 \\
\hline $\mathrm{Zn}$ & 12848 & 7006 & 9170 & 4770 & 15710 & 9210 & 3253 & 1803 \\
\hline $\mathrm{Ag}$ & 18 & 9 & 14 & 6 & 20 & 12 & 3 & 2 \\
\hline $\mathrm{Mn}$ & 2666 & 1416 & 1780 & 780 & 3330 & 2220 & 800 & 471 \\
\hline $\mathrm{As}$ & 1455 & 1190 & 1312 & 857 & 1554 & 1487 & 128 & 224 \\
\hline $\mathrm{Cd}$ & 40 & 24 & 31 & 20 & 51 & 27 & 8 & 3 \\
\hline $\mathrm{Sb}$ & 232 & 165 & 203 & 138 & 256 & 169 & 26 & 12 \\
\hline $\mathrm{Ba}$ & 580 & 312 & 420 & 150 & 710 & 530 & 131 & 186 \\
\hline
\end{tabular}

Consequently the measured water leachable metal concentrations posed significant environmental risk confirming the need for reducing potentially toxic elements' mobility using a stabilization method. Water leachable concentrations after treatment indicated that the performed remediation method reduced significantly the readily bioaccessible water leachable fraction of metals and subsequently the associated exposure risk to humans and biota. The corresponding reduction of water leachable metal fraction of metals in pilot scale application was determined as high as $17 \%$ for $\mathrm{Cu}, 50 \%$ for $\mathrm{Pb}, 45 \%$ for $\mathrm{Zn}, 41 \%$ for $\mathrm{Cd}, 46 \%$ for $\mathrm{Ag}, 18 \%$ for $\mathrm{As}, 47 \%$ for $\mathrm{Mn}, 45 \%$ for $\mathrm{Ba}$ and $29 \%$ for $\mathrm{Sb}$.

\subsection{Attapulgite "Geosynthetic Reactive Clay - GRC"}

The measured total concentrations of $\mathrm{Pb}, \mathrm{Zn}, \mathrm{As}, \mathrm{Cd}$ and $\mathrm{Sb}$ in the untreated soil from the school yard in Lavrion greatly exceeded the corresponding intervention values established by the "New Dutch List" (VROM 2009), indicating high poly-metallic soil pollution and presenting high risk of adverse health effects for children exposed to soil contamination (Kollios and Zotiadis, 2012). The mean values of metal concentration determined by water leaching experiments according to EN 12457-4 in the tested samples are presented in Table 2.

The water leachable metal concentrations in contaminated soil were lower than the corresponding limit values for non-hazardous wastes but exceeded the limit values for inert wastes assigned by Directive 2003/33/EC. As a fact the measured water leachable metal values in contaminated soil pose a significant environmental risk confirming the need for reducing potentially toxic elements' mobility using a stabilization binder. On the other hand the water leachable metal values of vegetal soil and attapulgite clay as it was expected are significantly lower than the limit values for inert wastes. The mean values of metals determined by the performed up flow percolation tests are 
presented in Table 3. The determined leachable metal values by up flow percolation tests in column without attapulgite clay (blind sample) exceeded the corresponding limit values for inert wastes assigned by Directive 2003/33/EC for arsenic, lead and cadmium. However in the columns with attapulgite clay, a significant reduction of water leachable metal fraction was determined reaching percentages as high as $100 \%$ for $\mathrm{As}, 21 \%$ for $\mathrm{Ba}, 100 \%$ for $\mathrm{Cd}$, about $100 \%$ for $\mathrm{Pb}$, $100 \%$ for $\mathrm{Sb}$ and $88 \%$ for $\mathrm{Zn}$. Best results were achieved in the percolation test conducted with 10 $\mathrm{cm}$ attapulgite clay in the test column. Leachable metal concentration values in all tested columns filled with attapulgite clay were lower than the corresponding limit values for inert wastes assigned by Directive 2003/33/EC.

Table 2 - Water leachable $(\mathrm{L} / \mathrm{S}=10 \mathrm{~L} / \mathrm{Kg})$ metal mean values $(\mathrm{mg} / \mathrm{kg})$ of vegetal soil, contaminated soil, attapulgite clay (EN 12457) and corresponding limit values for inert and non-hazardous wastes according to $33 / \mathrm{EC} / 2003$.

\begin{tabular}{|c|c|c|c|c|c|}
\hline \multirow{2}{*}{ Metal } & \multicolumn{2}{|c|}{ Water leachable (L/S= 10 l/Kg) mean values } & \multicolumn{2}{c|}{ Limit Values } \\
\cline { 2 - 6 } & Vegetal Soil & Contaminated Soil & Attapulgite Clay & $\begin{array}{c}\text { Inert } \\
\text { Wastes }\end{array}$ & $\begin{array}{c}\text { Non Hazardous } \\
\text { Wastes }\end{array}$ \\
\hline $\mathrm{As}$ & 0.012 & 1.45 & nd & 0.5 & 2 \\
\hline $\mathrm{Ba}$ & $\mathrm{nd}$ & 0.74 & $\mathrm{nd}$ & 20 & 100 \\
\hline $\mathrm{Cd}$ & 0.0028 & 0.04 & 0.0012 & 0.04 & 1 \\
\hline $\mathrm{Cu}$ & 0.08 & 0.54 & 0.036 & 2 & 50 \\
\hline $\mathrm{Hg}$ & $\mathrm{nd}$ & $\mathrm{nd}$ & $\mathrm{nd}$ & 0.01 & 0.2 \\
\hline $\mathrm{Mo}$ & $\mathrm{nd}$ & 0.05 & 0.011 & 0.5 & 10 \\
\hline $\mathrm{Ni}$ & 0.06 & 0.02 & 0.024 & 0.4 & 10 \\
\hline $\mathrm{Pb}$ & 0.01 & 9.20 & nd & 0.5 & 10 \\
\hline $\mathrm{Sb}$ & $\mathrm{nd}$ & 0.035 & $\mathrm{nd}$ & 0.06 & 0.7 \\
\hline $\mathrm{Se}$ & $\mathrm{nd}$ & $\mathrm{nd}$ & $\mathrm{nd}$ & 0.1 & 0.5 \\
\hline $\mathrm{Zn}$ & 1.4 & 12.85 & 1.1 & 4 & 50 \\
\hline
\end{tabular}

nd : not detected

\subsection{Attapulgite Clay in the Treatment of Sewage Sludge}

The effectiveness of attapulgite clay treatment was assessed by comparing the analytical results of leached solutions of treated and untreated sludge (reference sample SLU). The results showed a significant reduction of water leachable fraction for several. Overall the best results were achieved with the $10 \%$ mixing proportion of clay. The fine grained material performed better in removing phenol and DOC content in the leachate (100\% and 42\% reduction respectively in sample SL5F) but the coarse grained material (SL10C) achieved better reduction percentages for metal and metalloid parameters: As (39\%), Cu (64\%), $\mathrm{Hg}(100 \%)$, Mo (52\%), Pb (50\%), Zn (38\%). The order of metal and metalloid uptake by attapulgite clay was $\mathrm{Hg}>\mathrm{Cu}>\mathrm{Mo}>\mathrm{Pb}>\mathrm{Se}>\mathrm{As}>\mathrm{Zn}$.

With respect to pathogens, results at the end of the experimental period in the untreated and treated samples were compared to pathogen concentrations in the initial sludge sample (Figure 3). A significant reduction in Coliforms, up to $86 \%$ was observed for sample SL10C. Samples treated with $10 \%$ fine grained attapulgite clay achieved the best reduction in pathogens overall. It is noted that Salmonella spp and Listeria monocytogenes were absent even in the initial sample. Mixing also reduced the moisture content of treated material. 
Table 3 - Metal water leachable mean values $(\mathrm{mg} / \mathrm{L})$ of up flow percolation tests (CEN/TS 14405) in the tested GRC.

\begin{tabular}{|c|c|c|c|c|c|}
\hline Metal & $\begin{array}{c}\text { Percolation } \\
\text { Test } *\end{array}$ & $\begin{array}{c}\text { Percolation } \\
\text { Test } * *\end{array}$ & $\begin{array}{c}\text { Percolation } \\
\text { Test } * * *\end{array}$ & $\begin{array}{c}\text { Inert } \\
\text { (Co) }\end{array}$ & $\begin{array}{c}\text { Non } \\
\text { Hazardous (Co) }\end{array}$ \\
\hline $\mathrm{As}$ & 0.007 & nd & nd & 0.06 & 0.3 \\
\hline $\mathrm{Ba}$ & 0.660 & 0.580 & 0.520 & 4.0 & 20 \\
\hline $\mathrm{Cd}$ & 0.021 & 0.003 & 0.002 & 0.02 & 0.3 \\
\hline $\mathrm{Cu}$ & 0.011 & $<0.003$ & $<0.003$ & 0.6 & 30 \\
\hline $\mathrm{Hg}$ & $\mathrm{nd}$ & $\mathrm{nd}$ & $\mathrm{nd}$ & 0.002 & 0.03 \\
\hline $\mathrm{Mo}$ & $<0.003$ & $<0.003$ & $<0.003$ & 0.2 & 3.5 \\
\hline $\mathrm{Ni}$ & 0.002 & 0.005 & 0.008 & 0.12 & 3 \\
\hline $\mathrm{Pb}$ & 0.320 & $<0.003$ & $<0.003$ & 0.15 & 3 \\
\hline $\mathrm{Sb}$ & 0.040 & $\mathrm{nd}$ & $\mathrm{nd}$ & 0.1 & 0.15 \\
\hline $\mathrm{Se}$ & $\mathrm{nd}$ & $\mathrm{nd}$ & $\mathrm{nd}$ & 0.04 & 0.2 \\
\hline $\mathrm{Zn}$ & 0.220 & 0.032 & 0.027 & 1.2 & 15 \\
\hline
\end{tabular}

$*, * *, * * *$ : Testing column with $0 \mathrm{~cm}^{*}, 5 \mathrm{~cm}^{* *}, 10 \mathrm{~cm} * * *$ attapulgite clay.

\subsection{Effectiveness of Attapulgite Clay as Contaminated Soil and Biosolids Amendment and Future Research Directions}

The effectiveness of metal stabilization techniques on soil depends upon numerous factors besides the type of binder, including physical (i.e. grain size, plasticity, permeability, moisture content, etc.) and geochemical characteristics (type of contaminant, concentration, heterogeneity, leachability, mineralogy, $\mathrm{pH}, \mathrm{Eh}$, etc.) of the soil and on other competitive factors (USEPA, 2003). Soil solution $\mathrm{pH}$ is an important variable which controls the adsorption of the metal at clay water interfaces. Clays are known to possess a negative surface charge in solution.

The main mechanisms of toxic metals adsorption/ sorption on attapulgite clay have been studied by many researchers. Potgieger et al. (2006) showed that at slightly alkaline conditions more of the positively charged metal ions are adsorbed on the negative clay surface and precipitation of metal hydroxides occurs. Alvarez-Ayuso et al. (2003) suggested reaction of heavy metals with numerous silanol groups. Shirvani et al. (2006) also suggested two mechanisms for adsorption, i.e. replacement of $\mathrm{Mg}^{2+}$ in the edges of octahedral layer and inner-sphere complexation on the functional groups on the broken edges of the mineral. Furthermore data of Cai \& Xue (2008) confirmed three mechanisms for copper adsorption by palygorskite: (a) onto the surface or in a net-like interstice; (b) forms a Me-complex ion and is trapped in the channel; or (c) into the hexagonal channel of the tetrahedral sites or the unoccupied octahedral sites of the mineral.

Laboratory experimental results indicated that treating sewage sludge with attapulgite clay might have positive effects in reducing the mobility and thus bioavailability of toxic elements in the instance of sludge land application. However, heavy metal content of sewage sludge is variable and hardly comparable (Fuerhacker and Haile, 2011). Furthermore, the fate and transport, mobility, bioavailability and eco-toxicity of potentially harmful elements in sludge-amended soils depends on several factors including $\mathrm{pH}$, cation exchange capacity, organic matter content, soil structure and texture (Basta et al., 2005). All of the above calls for further work in order to explore the speciation of potentially harmful elements in sludge and understand the processes controlling adsorption by attapulgite clay. Besides the stabilization of harmful substances in sewage sludge, attapulgite clay could be used as an amendment for sewage sludge composting. In the initial stage of sludge treatment it reduces the moisture content, improves plasticity, reduces odor and prevents 
ammonia losses (Xie et al. 2012). Furthermore it enhances the composting procedure by increasing aerisation and optimizing the required conditions, thus contributing to the production of an organohumus compost which is an added value fertilizer for agricultural applications.

Based on our experimental data as well as the relevant literature it is possible that the effectiveness of the attapulgite clay as a binder for toxic elements stabilization in contaminated soil could be attributed to a combination of factors such as a) direct precipitation as a result of control and time sustention of $\mathrm{pH}$ levels to slightly alkaline, b) high adsorption capacity as a result of its high specific surface area, c) sorption capacity derived by the existence of nanopores within the free channels of mineral structure. Further experiments employing advanced techniques utilizing synchrotron light sources such as X-ray absorption fine structure (XAFS) spectroscopy can be used to derive information on the structure and attachment geometry of sorption complexes on mineral surfaces in contact with aqueous solution (Brown and Calas, 2013). Evidence of this type of study combined with further empirical data from laboratory and field scale experiments will shed light into the controlling mechanism of metal sorption by attapulgite clay.

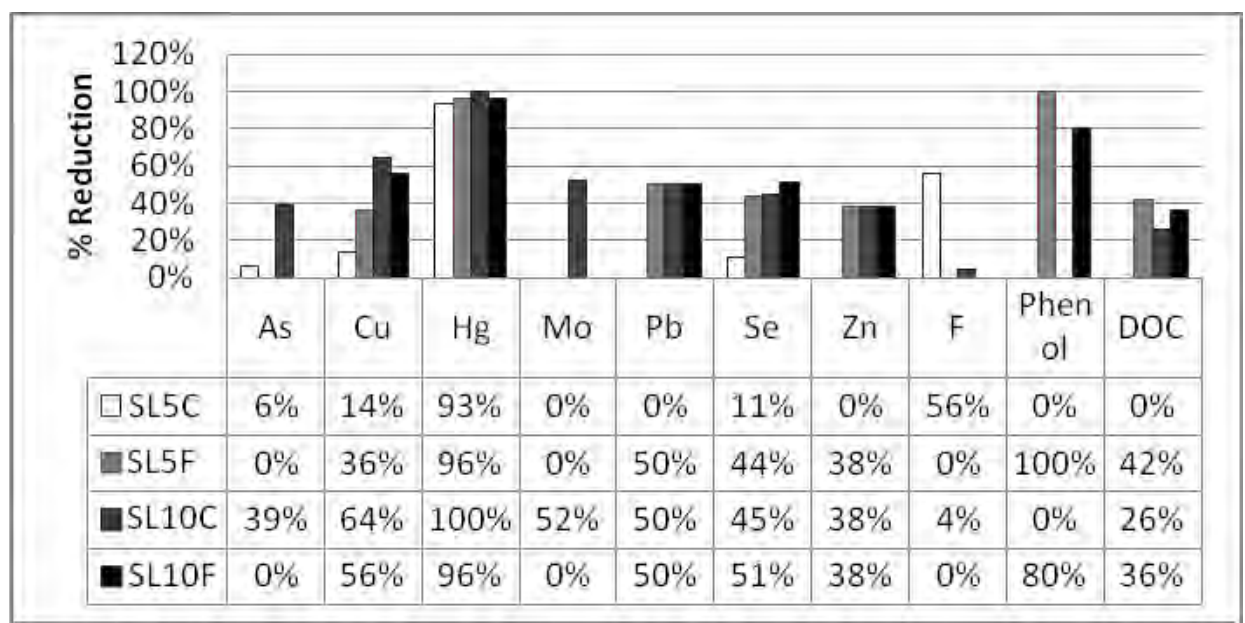

Figure 2 - Reduction (\%) in water leachable fraction of selected sludge parameters after treatment with different proportions of coarse (C) and fine (F) attapulgite clay.

\begin{tabular}{|c|c|c|c|c|c|}
\hline \multirow[t]{2}{*}{ 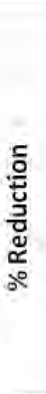 } & \multirow[t]{2}{*}{$\begin{array}{r}100 \\
90 \\
80 \\
70 \\
60 \\
50 \\
40 \\
30 \\
20 \\
10 \\
0\end{array}$} & 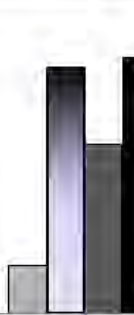 & & & \\
\hline & & Coliforms & Fecal coliforms & $\begin{array}{l}\beta \text {-glucuronidase } \\
\text { positive } E \text {. coll }\end{array}$ & Enterococci \\
\hline & J final & 0 & 99 & 90 & 65 \\
\hline & & 16 & 99 & 74 & 81 \\
\hline & LOF & 83 & 100 & 98 & 85 \\
\hline & & 57 & 94 & 14 & 0 \\
\hline & $10 \mathrm{C}$ & 86 & 99 & 83 & 58 \\
\hline
\end{tabular}

Figure 3 - Reduction (\%) in microbiological parameters of sludge after treatment with different proportions of coarse (C) and fine (F) attapulgite clay.

XLVII. No $2-999$ 


\section{Conclusions}

A series of batch and pilot scale applications of attapulgite clay have demonstrated the effectiveness of this natural material as an amendment for the stabilization of metals in contaminated soil and sewage sludge. The feasibility of applying attapulgite clay as a binder for in - situ stabilization of toxic metals in contaminated soil was demonstrated in a pilot scale experiment at Lavrion. The reduction of water leachable metal fraction of metals was determined as high as $17 \%$ for $\mathrm{Cu}, 50 \%$ for $\mathrm{Pb}, 45 \%$ for $\mathrm{Zn}, 41 \%$ for $\mathrm{Cd}, 46 \%$ for $\mathrm{Ag}, 18 \%$ for $\mathrm{As}, 47 \%$ for $\mathrm{Mn}, 45 \%$ for $\mathrm{Ba}$ and $29 \%$ for $\mathrm{Sb}$. Results from this study proved that the presence of attapulgite clay reduced significantly the water leachable metal concentrations and subsequently the associated environmental risk to humans and biota. In a different study, attapulgite clay was applied as an amendment sandwiched between two geotextiles by means of a new type of geocomposite material, named "Geosynthetic Reactive Clay - GRC" for toxic metals retention in contaminated land. The effectiveness of this innovative commercial product was assessed in a pilot scale study on a heavily contaminated site.

Also, research results indicated that the use of attapulgite clay has a positive potential in the treatment of sewage sludge. Laboratory scale experiments showed that mixing with $10 \%$ attapulgite clay reduces significantly the leachable concentrations of several parameters and that it is mostly effective for removal of phenol, $\mathrm{DOC}, \mathrm{Hg}, \mathrm{Cu}, \mathrm{Mo}, \mathrm{Pb}, \mathrm{Se}$, As and $\mathrm{Zn}$. Treatment was also effective in the reduction of pathogen concentrations in sludge after the 4 weeks observation period. It is proposed that the method is further tested in a pilot scale field experiment combined with composting in order to further reduce the organic component and pathogens in sludge.

Overall, development and application of attapulgite clay as a binder for immobilizing metals in contaminated soil and biosolids is a promising and cost-effective remediation technique under present market conditions. However, further research is needed in order to explore the mechanism that controls metal sorption by attapulgite clay. Once this is understood many more applications of this natural material will become possible.

\section{Acknowledgments}

The authors acknowledge the input of various collaborators from the industry and the local authorities in this research, including Edafomichaniki S.A., Thrace Non Wovens \& Geosynthetics S.A., Municipality of Lavrion, Municipality and DEYA of Thera Island. Also we thank the postgraduate students E. Theologou and A.E. Gidaropoulou for their contribution in sampling and chemical analysis in two of the discussed projects. Special thanks are due to GEOHELLAS S.A. for supporting technically and financially the research on development of innovative environmental applications for attapulgite clay.

\section{References}

Álvarez-Ayuso E. and García-Sánchez A. 2003. Palygorskite as a Feasible Amendment to Stabilize Metal Polluted Soils, Environmental Pollution, 125, 337-344.

Basta N.T., Ryan J.A. and Chaney R.L. 2005. Trace element chemistry in residual-treated soil: key concepts and metal bioavailability, Environ Quality, 34, 49-63.

Brown G. E. Jr. and Calas G. 2013. Mineral-Aqueous Solution Interfaces and Their Impact on the Environment, Geochemical Perspectives, 1, (4-5), 483-737.

Cai Y. F. and Xue J. Y. 2008. A study of adsorption and ab-sorption mechanisms of copper in palygorskite, Clay Minerals, 43, (2), 195-203.

CEN/TS 14405, 2004. Characterization of waste-Leaching behaviour tests-Up-flow percolation test (under specified conditions).

$\underline{\text { XLVII, No } 2-1000}$ 
Council Directive 2003/33/EC Establishing criteria and procedures for the acceptance of waste at landfills pursuant to Article 16 of and Annex II to Directive 1999/31/EC, 19 December 2002, Official Journal of the European Communities, L11/27 - 49.

EN 12457-4:2003. Characterization of waste - Leaching; Compliance test for leaching of granular waste materials and sludges - Part 4: One-stage batch test at a liquid to solids ratio of 10 $\mathrm{l} / \mathrm{kg}$ for materials with particle size below $10 \mathrm{~mm}$. European Committee for Standardization.

Fuerhacker M. and Haile T. M. 2011. Treatment and reuse of sludge, in: D.Barcelo and M.Petrovic (eds.) Waste Water Treatment and Reuse in the Mediterranean Region, Hdb Env Chem, 14, 63-92.

Galan E. 1996. Properties and applications of palygorskite-sepiolite clays, Clay Minerals, 31, 443453.

Gidaropoulou A.E., Argyraki A., Zotiadis V. and Kacandes G. 2012. A laboratory scale study on sewage sludge treatment by attapulgitic clay, Proceedings of $4^{\text {th }}$ International Conference EEDSA: Solid Waste Treatment in Crisis (ISBN: 978-960-6865-54-1). Athens, 30 November - 1 December 2012, 379-386.

Gionis V., Kacandes G.H., Kastritis I.D. and Chryssikos, G.D. 2006. On the structure of palygorskite by mid- and near-infrared spectroscopy, American Mineralogist, 91, 1125-1133.

Kollios A. and Zotiadis V. 2012. Design and Application of an Innovative Remediation Technique against Toxic Metals Contaminated Soil in Urban Areas, Proceedings of 5th European Geosynthetics Congress (EUROGEO 5), 16-19 September 2012, Valencia, Spain.

O’Day P.A. and Vlassopoulos D., 2010. Mineral-based amendments for remediation, Elements, 6, 375-381.

Potgieter J.H., Potgieter-Vermaak S.S. and Kalibantonga P.D. 2006. Heavy metals removal from solution by palygorskite clay, Minerals Engineering, 19, 463-470.

Shirvani M., Kalbasi M., Shariatmadari H., Nourbakhsh F. and Najafi B. 2006. Sorptiondesorption of cadmium in aqueous palygorskite, sepiolite and calcite suspensions: Isotherm hysteresis, Chemosphere, 65, 2178-2184.

US Environment Protection Agency, 2003. Guidance on the use of Stabilisation/Solidification for the Treatment of Contaminated Soil, R\&D Technical Report P5-064/TR/1.

Veli S. and Alyüz B. 2007. Adsorption of copper and zinc from aqueous solutions by using natural clay, Journal of Hazardous Materials, 149, 226-233.

VROM 2009. Soil Remediation Circular 2009, The Ministry of Housing, Spatial Planning and Environment, Directorate General For Environmental Protection, Netherlands.

Xie K., Jia X., Xu P., Huang X., Gu W., Zhang F., Yang S., and Tang S. 2012.The addition of modified attapulgite reduces the emission of nitrous oxide and ammonia from aerobically composted chicken manure, Journal of the Air \& Waste Management Association, 2(10):1174-1181, 2012.

Zhang M. and Pu, J. 2011. Mineral materials as feasible amendments to stabilize heavy metals in polluted urban soils, Journal of Environmental Sciences, 23, 607-615.

Zhen Li, Lin Yin and Kun He. 2006. Iron-rich palygorskite: A potential clay material for contaminated environment remediation, Chinese Journal of Geochemistry, 25, Supplement 1/ March, 2006.

Zotiadis V., Argyraki A. and Theologou E. 2012. A Pilot Scale Application of Attapulgitic Clay for Stabilization of Toxic Elements in Contaminated Soil, Journal of Geotechnical and Geoenvironmental Engineering, 138, (5), 633-637. 